\title{
Confirmation by fluorescent tracer of coverage of onion leaves for control of onion thrips using selected nozzles, surfactants and spray volumes
}

\author{
Jennifer K. MacIntyre-Allen ${ }^{\mathrm{a}, *}$, Jeff H. Tolman ${ }^{\mathrm{b}}$, Cynthia D. Scott-Dupree ${ }^{\mathrm{a}}$, C. Ron Harris ${ }^{\mathrm{a}}$ \\ ${ }^{a}$ Department of Environmental Biology, University of Guelph, Guelph, Ont., Canada N1G 2 W1 \\ ${ }^{\mathrm{b}}$ Agriculture and Agri-Food Canada, Southern Crop Protection and Food Research Centre, 1391 Sandford Street, London, Ont., Canada N5V $4 T 3$
}

Received 16 August 2006; received in revised form 2 February 2007; accepted 2 February 2007

\begin{abstract}
Track sprayer and field sprayer trials were completed to assess the effect of different nozzles, surfactants and carrier volumes on product delivery to the inner leaves of onion plants using a fluorescent tracer. Track sprayer trials revealed more tracer on the inner leaves of onions using either the TeeJet ${ }^{\circledR}$ XR8004 flat fan or D4/DC25 disc-core hollow cone nozzles. In three of four experiments, more tracer was detected on onions sprayed alone or combined with Sylgard ${ }^{\mathbb{B}} 309$ at $200 \mathrm{~L} /$ ha than plants sprayed with tracer + Companion $^{\mathbb{R}}$. When the carrier volume was increased to $400 \mathrm{~L} / \mathrm{ha}$, more tracer was detected on onions sprayed alone or combined with Companion. In field trials, the XR8004 delivered more tracer than the D4/DC25 $(F=32.8 ; P<0.00$; d.f. $=1,77)$. The best coverage was observed on plants sprayed with the flat fan combined with Agral $^{\mathbb{R}} 90$, sprayed at either $400 \mathrm{~L} /$ ha $(29 \%$ coverage $)$ or $600 \mathrm{~L} /$ ha $(23 \%$ coverage).
\end{abstract} (C) 2007 Elsevier Ltd. All rights reserved.

Keywords: Fluorescent tracer; Onion thrips; Pest control; Nozzles; Surfactants

\section{Introduction}

Onion thrips, Thrips tabaci Lindeman, are economic pests of Allium spp. worldwide (Horsfall and Fenton, 1922; Boyce and Miller, 1954; Theunissen and Legutowska, 1991; Brewster, 1994). Adult and immature onion thrips feed by piercing and rasping leaf tissues, removing the cell contents and destroying chlorophyll-rich leaf mesophyll (Molenaar, 1984). The feeding damage is characterized by white or silvery lesions and can result in reduced yield and increased susceptibility to infection by plant pathogens (Howard et al., 1994; Mckenzie et al., 1993).

Onion thrips nymphs, the predominant lifestage throughout the Ontario growing season (MacIntyre-Allen, 2004), congregate deep within the axils of onion leaves and are thus well protected from foliar-applied chemical

\footnotetext{
${ }^{*}$ Corresponding author. Ontario Ministry of Agriculture, Food and Rural Affairs, 1 Stone Road, Guelph, Ont., Canada N1G 4 Y2. Tel.: + 15198264963 ; fax: + 15198264964 .

E-mail address: jennifer.allen@ontario.ca (J.K. MacIntyre-Allen).
}

control agents. This behaviour, coupled with the potentially rapid increase of field populations under favourable conditions, continues to frustrate growers attempting to control this pest around the world (Sites et al., 1992; Lewis, 1997; Murai, 2000).

In Ontario, foliar applications of one of the five registered insecticides are recommended for onion thrips control (OMAFRA, 2006). Three of the five products, deltamethrin, lambda-cyhalothrin and cypermethrin, are pyrethroids while the remaining two products, diazinon and dibrom, are organophosphorus insecticides. Depending on the season, growers apply 2-10 sprays to manage onion thrips in carrier volumes ranging from 200 to $400 \mathrm{~L} / \mathrm{ha}$. In Canada, the Pest Control Products Act requires pesticide-surfactant combinations be registered for inclusion on product labels. Currently, products registered for use on onions for onion thrips control does not include surfactant registrations.

Pesticide performance is based on a particular insect, a particular host, and a particular chemical. Under laboratory conditions, an insecticide may be applied and control 
evaluated, often without consideration of the insect-plant interaction. While Crosby (1973) estimated that only $1 \%$ of insecticide reaches the intended target under field conditions, work by Hall and Adams (1990) suggests that even less than $1 \%$ of insecticide reaches the target. The insect-plant interaction must therefore be considered before an insecticide application is made to maximize delivery and subsequent performance of the control agent. To maximize delivery to the pest, growers should use equipment best-suited for the intended pest and crop. An investigation to optimize spray application systems to improve efficacy of control agents for onion thrips by maximizing delivery into the onion leaf axil was therefore initiated.

There are many types of spray nozzles available, each with characteristic spray angle, droplet size, or spray pattern. Three different components of a typical spray delivery system were investigated: (1) spray nozzle, (2) surfactant, and (3) carrier volume.

\section{Materials and methods}

\subsection{Track sprayer trials}

All trials were conducted on onion plants grown from set onion bulbs planted in fibre trays $(27 \mathrm{~cm} \times 16.5 \mathrm{~cm} \times 8.5 \mathrm{~cm}$ deep) (Kord Products Ltd., Bramalea, Ont.) filled with Premier ProMix BX growing medium (Premier Horticulture, Dorval, Que.). Each fibre tray was planted with approximately 22 onion bulbs in $2 \times 2$ rows with $2.5 \mathrm{~cm}$ spacings between bulbs. Onions were maintained in a greenhouse at the Southern Crop Protection and Food Research Centre-Agriculture and Agri-Food Canada in Delhi, Ontario. Trays of onions were transported to the University of Guelph when onions reached a height of $20-25 \mathrm{~cm}$ and had produced approximately $4-5$ leaves.

Nozzles delivering different spray angles, droplet sizes and patterns were evaluated at several application pressures in 2002 (four nozzles) and 2003 (three nozzles) (Table 1). Tinopal CBS-X (Ciba-Geigy, Greensboro, NC) (tracer), a water-soluble fluorescent tracer dye, was used to visualize spray depositions. In all trials, the tracer was applied at a concentration of $15 \mathrm{mg} / \mathrm{L}$ in reverse osmosis (RO) water. Tinopal fluoresces brilliant blue-violet (Staniland, 1958) with an absorption maximum of $349 \mathrm{~nm}$ and an emission maximum of $440 \mathrm{~nm}$ is commonly used in spray deposition studies (Downer et al., 1997; Barber and Parkin, 2003; Barber et al., 2003).

Onion plants were sprayed with one of the following tracer + surfactant treatments: tracer, tracer + Sylgard 309 $[(0.375 \%, v / v)$ (siloxylated polyether) (Dow Corning Corp., Midland, MI)] or tracer + Companion $[(0.2 \%, \mathrm{v} / \mathrm{v})$ (octylphenoxy polyethoxy-9-ether) (Dow AgroSciences, Calgary, Alta.)] using a motorized track sprayer (Research Instrument Co., Guelph, Ont.). In all experiments, the motorized track sprayer was equipped with a single nozzle. Between experiments, equipment was cleaned and the
Table 1

Nozzle type ${ }^{\mathrm{a}}$, carrier volume and surfactant combinations tested

\begin{tabular}{|c|c|c|}
\hline Nozzle type & $\begin{array}{l}\text { Carrier } \\
\text { volume } \\
\text { (L/ha) }\end{array}$ & Surfactants tested \\
\hline \multicolumn{3}{|l|}{ Track sprayer trials } \\
\hline \multicolumn{3}{|l|}{2002} \\
\hline XR8003 extended range flat & 200 & $\begin{array}{l}\text { Sylgard }^{\circledR} 309, \\
\text { Companion }^{\circledR}\end{array}$ \\
\hline XR8004 extended range flat & 200 & $\begin{array}{l}\text { Sylgard 309, } \\
\text { Companion }\end{array}$ \\
\hline TJ60-8004 vs twinjet & 200 & $\begin{array}{l}\text { Sylgard 309, } \\
\text { Companion }\end{array}$ \\
\hline D4/DC25 disc-core type cone & 200 & $\begin{array}{l}\text { Sylgard 309, } \\
\text { Companion }\end{array}$ \\
\hline \multicolumn{3}{|l|}{2003} \\
\hline XR8004 extended range flat & 400 & $\begin{array}{l}\text { Sylgard 309, } \\
\text { Companion }\end{array}$ \\
\hline TJ60-8004 vs twinjet & 400 & $\begin{array}{l}\text { Sylgard 309, } \\
\text { Companion }\end{array}$ \\
\hline D4/DC25 disc-core hollow cone & 400 & $\begin{array}{l}\text { Sylgard 309, } \\
\text { Companion }\end{array}$ \\
\hline \multicolumn{3}{|l|}{ Field sprayer trials } \\
\hline \multicolumn{3}{|l|}{2003} \\
\hline XR8004 extended range flat & 400,600 & $\begin{array}{l}\text { Sylgard 309, Agral } \\
90^{\mathbb{R}}, \text { LI-700 }\end{array}$ \\
\hline D4/DC25 disc-core hollow cone & 400,600 & $\begin{array}{l}\text { Sylgard } 309, \text { Agra } \\
90, \text { LI-700 }\end{array}$ \\
\hline
\end{tabular}

${ }^{\mathrm{a}}$ Spraying Systems Co., Wheaton, IL, USA.

nozzle changed. In experiments $1-4$, four different TeeJet nozzles were tested: XR8003 flat fan, XR8004 flat fan, TJ60-8004 twin jet and D4/DC25 hollow cone. In experiments 5 and 6 , three different nozzles were evaluated: XR8004, TJ60-8004 and D4/DC25. For all spray runs, each nozzle was calibrated to deliver either $200 \mathrm{~L} / \mathrm{ha}$ (one pass) at $276 \mathrm{kPa}$ (experiments 1-3) or $400 \mathrm{~L} / \mathrm{ha}$ (two passes) at $276 \mathrm{kPa}$ (experiments 4-6). For each experiment, the spray nozzle was positioned $35 \mathrm{~cm}$ above the plant canopy and the sprayer speed was $1.15 \mathrm{~km} / \mathrm{h}$. Each replicate of a given treatment was sprayed during a separate pass of the track sprayer. Treated onions plants were allowed to dry in the dark for $2 \mathrm{~h}$.

To compare droplet deposition, onion plants were returned to the laboratory and eight onion plants were harvested from each of three replicates for each tracer + surfactant combination. The outer leaves were removed leaving only the two inner leaves for each plant. Using individual razor blades, the two inner leaves were sectioned into three or four $2 \mathrm{~cm}$ regions (Fig. 1). Region 1 encompassed the leaf area closest to the growing point, the location where the majority of nymphs are found throughout the growing season. Using forceps, the two leaves for each cut region of each plant were transferred into a labelled $20-\mathrm{mL}$ glass scintillation vial (Fisher Scientific, Unionville, Ont.) containing $2 \mathrm{~mL}$ of RO water.

The onion segments in each vial were swirled for $30 \mathrm{~s}$, removed with clean forceps and discarded. Vials were 


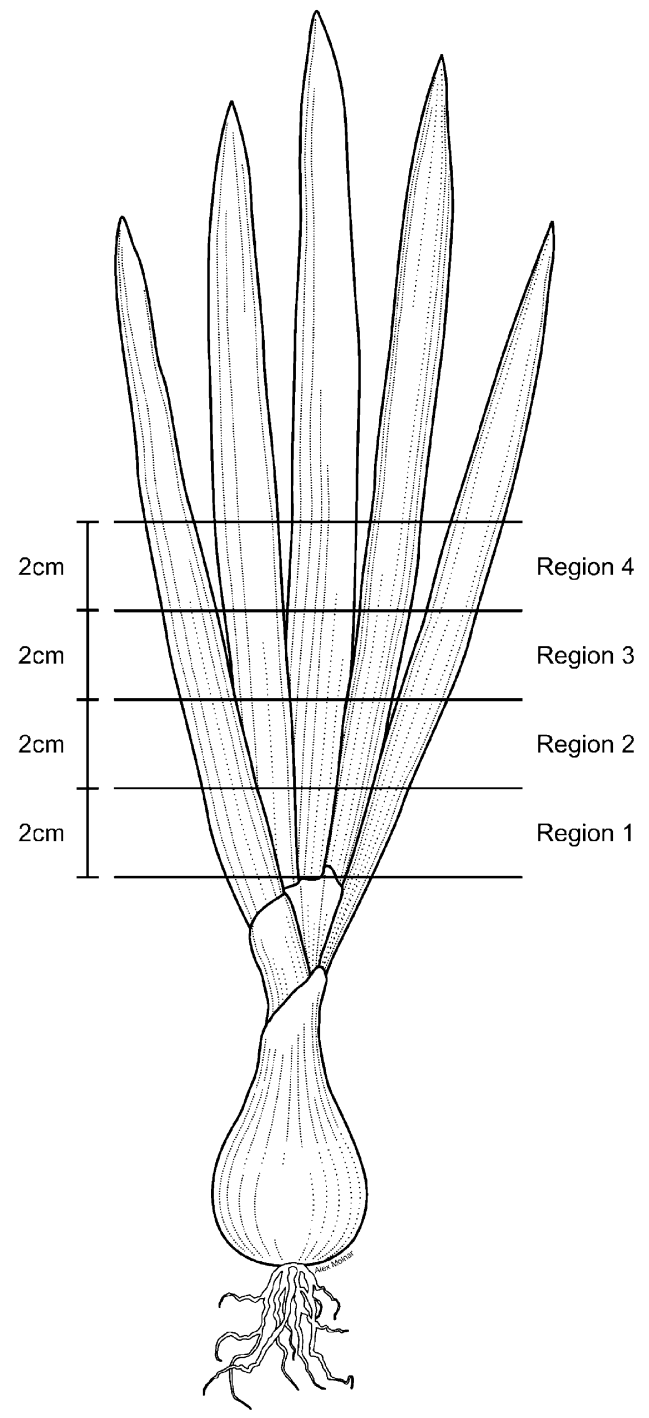

Fig. 1. Onion plant schematic demonstrating leaf regions selected for study in track sprayer trials.

capped, placed into cardboard boxes, covered with aluminum foil and stored at $4{ }^{\circ} \mathrm{C}$ for further analysis. For each experiment, control vials were also prepared using onions sprayed with RO water only.

Samples of $200 \mu \mathrm{L}$ were pipetted from each vial into a well of a 96-well microtitre plate (Diamed Lab Supplies, Mississauga, Ont.). The concentration of tracer for each treatment was measured fluorimetrically with a MFX Microtitre $^{\mathrm{TM}}$ Plate Fluorometer (Dynex Technologies, Virginia, USA) in conjunction with Dynex Revelation 4.02 software (Dynex, 1999[h1]). Background fluorescence of control onions sprayed with RO water was determined and subtracted from all treatments.

\subsection{Field sprayer trial}

Dry yellow seed cooking onion seed (cv. Prince) was hand planted ( 135 seeds/row) in three-row microplots $(2.25 \mathrm{~m}$ long $\times 0.9 \mathrm{~m}$ wide) (Harris et al., 1971) at the
Southern Crop Protection and Food Research CentreAgriculture and Agri-Food Canada in London, filled with insecticide-residue-free organic soil on 9 May 2003. Within each microplot, onion seeds were spaced $2 \mathrm{~cm}$ apart within row and $30 \mathrm{~cm}$ between rows. Tracer plus one of the following three surfactants [Sylgard $309(0.375 \%, \mathrm{v} / \mathrm{v})$, Agral 90 (nonylphenoxy polyethoxyethanol) $(0.2 \%, \mathrm{v} / \mathrm{v})$ (Norac Concepts Inc., Ottawa, Ont.) or LI-700 (0.5\%, v/v) (phosphatidylcholine methylacetic acid alkyl polyoxyethylene) (Loveland Industries, Greely, CO)], applied in one of two carrier volumes $(400 \mathrm{~L} / \mathrm{ha}$ or $600 \mathrm{~L} / \mathrm{ha})$ using one of two nozzles (TeeJet XR8004 flat fan or TeeJet D4/DC25 disc-core) were tested. All treatments were replicated twice in a randomized complete block design. On 14 August 2003, each tracer + surfactant combination was applied at $276 \mathrm{kPa}$ to onion plants (eight-leaf stage) using a hand-held, $\mathrm{CO}_{2}$ pressurized R\&D field-plot sprayer (R\&D Sprayers, Opelousas, LA) fitted with either a single XR8004 flat fan or a D4/DC25 disc-core nozzle. The nozzle was positioned approximately $30 \mathrm{~cm}$ above the plant canopy. Two hours after application, six plants from each plot were carefully pulled, placed in individual labelled boxes, and returned to the laboratory. The inner three leaves of each plant were examined under an UVL-18 ultraviolet lamp (VWR Canlab, Toronto, Ont.) and the total amount of visible Tinopal was estimated using a plant pathogen percent rating system for cereals (Anonymous, 1975).

\subsection{Data analysis}

Spray deposition on selected onion samples was analysed as a factorial analysis of variance (ANOVA) with three factors: nozzle, surfactant and onion leaf region in Track Sprayer Trials or with nozzle, surfactant and carrier volume in Field Sprayer Trials (Statistix 2.2, Tallahassee, FL). Means were separated using Fisher's protected least significant difference (LSD) test.

\section{Results}

\subsection{Track sprayer trials}

In experiment 1 , significantly more tracer was deposited onto onion leaves by the XR8004 or D4/DC25 nozzles than either XR8003 or TJ60 8004 nozzles (Table 2a). Significantly more tracer was recorded on onion leaves sprayed with Sylgard than any other tracer + surfactant combination. The highest amount of tracer was recorded in Region 2, which received $39.6 \%$ of the total tracer recorded. Further analysis revealed significant interactions among nozzles, surfactants and regions $(F=3.99$; $P=0.001$; d.f. $=18,96$ ). Two treatment combinations delivered significantly more tracer than all other combinations tested. One combination, the XR8004 nozzle and tracer + Sylgard, resulted in 127.8 FSU/onion (fluorescent units/onion) on Region 3. The second combination of the D4/DC25 nozzle and tracer + Sylgard resulted in 
Table 2

Relative effectiveness of combinations of nozzle type and surfactants for deposition of Tinopal CBS-X, based on mean fluorescence units (FSU), on various regions of onion leaves (see Fig. 1) applied in a track sprayer

\begin{tabular}{|c|c|c|c|c|c|}
\hline \multirow[t]{2}{*}{ Parameters } & \multicolumn{4}{|c|}{ Mean $($ FSU/onion $) \pm$ SEM } & \multirow[t]{2}{*}{ Statistics } \\
\hline & $\begin{array}{l}\text { TeeJet }^{\circledR} \text { XR8003 } \\
\text { Region 1 } \\
\text { Sylgard }^{\circledR} 309\end{array}$ & $\begin{array}{l}\text { TeeJet }^{\circledR} \text { XR8004 } \\
\text { Region 2 } \\
\text { Companion }\end{array}$ & $\begin{array}{l}\text { TeeJet }^{\circledR} \text { D4/DC25 } \\
\text { Region } 3 \\
\text { No surfactant }\end{array}$ & $\begin{array}{l}\text { TeeJet }^{\circledR} \text { TJ60 } 8004 \\
\text { Region } 4\end{array}$ & \\
\hline \multicolumn{6}{|c|}{ (a) Experiment 1} \\
\hline $\begin{array}{l}\text { Nozzle } \\
\text { Region } \\
\text { Surfactant }\end{array}$ & $\begin{array}{r}8.1 \pm 2.2 \mathrm{~b}^{*} \\
7.9 \pm 1.8 \mathrm{~b} \\
21.9 \pm 6.4 \mathrm{a}\end{array}$ & $\begin{array}{r}21.7 \pm 7.3 \mathrm{a} \\
21.2 \pm 5.7 \mathrm{a} \\
8.1 \pm 2.1 \mathrm{~b}\end{array}$ & $\begin{array}{l}19.2 \pm 5.4 \mathrm{a} \\
14.7 \pm 6.9 \mathrm{ab} \\
10.2 \pm 2.4 \mathrm{~b}\end{array}$ & $\begin{array}{l}4.6 \pm 1.6 \mathrm{~b} \\
9.8 \pm 3.3 \mathrm{~b}\end{array}$ & $\begin{array}{l}F=6.18 ; P=0.001 ; \text { d.f. }=3,96 \\
F=3.13 ; P=0.02 ; \text { d.f. }=3,96 \\
F=6.61 ; P=0.001 ; \text { d.f. }=2,96\end{array}$ \\
\hline $\begin{array}{l}\text { (b) Experiment } \\
\text { Nozzle } \\
\text { Region } \\
\text { Surfactant }\end{array}$ & $\begin{array}{r}11.2 \pm 2.1 \mathrm{~b} \\
26.2 \pm 4.7 \mathrm{a} \\
7.6 \pm 1.4 \mathrm{~b}\end{array}$ & $\begin{array}{c}8.8 \pm 1.3 \mathrm{~b} \\
7.5 \pm 1.1 \mathrm{~b} \\
14.7 \pm 2.0 \mathrm{ab}\end{array}$ & $\begin{array}{r}21.7 \pm 5.8 \mathrm{a} \\
6.3 \pm 0.8 \mathrm{~b} \\
17.8 \pm 4.9 \mathrm{a}\end{array}$ & $11.7 \pm 3.6 \mathrm{~b}$ & $\begin{array}{l}F=3.78 ; P=0.01 ; \text { d.f. }=3,72 \\
F=19.15 ; P=0.01 ; \text { d.f. }=2,72 \\
F=4.24 ; P=0.01 ; \text { d.f. }=2,72\end{array}$ \\
\hline $\begin{array}{l}\text { (c) Experiment } \\
\text { Nozzle } \\
\text { Region } \\
\text { Surfactant }\end{array}$ & $\begin{array}{l}29.6 \pm 4.3 \mathrm{~b} \\
70.9 \pm 11.8 \mathrm{a} \\
57.7 \pm 11.9 \mathrm{a}\end{array}$ & $\begin{array}{l}67.3 \pm 14.5 \mathrm{a} \\
26.9 \pm 4.3 \mathrm{~b} \\
37.4 \pm 5.8 \mathrm{~b}\end{array}$ & $\begin{array}{l}23.5 \pm 4.0 \mathrm{~b} \\
18.9 \pm 2.8 \mathrm{~b} \\
21.6 \pm 3.6 \mathrm{~b}\end{array}$ & $35.2 \pm 9.2 b$ & $\begin{array}{l}F=8.12 ; P=0.001 ; \text { d.f. }=3,72 \\
F=22.30 ; P=0.001 ; \text { d.f. }=2,72 \\
F=9.30 ; P=0.001 ; \text { d.f. }=2,72\end{array}$ \\
\hline $\begin{array}{l}\text { (d) Experiment } \\
\text { Nozzle } \\
\text { Region } \\
\text { Surfactant }\end{array}$ & $\begin{array}{r}59.4 \pm 13.3 \mathrm{~b} \\
164.9 \pm 27.6 \mathrm{a} \\
100.6 \pm 24.3 \mathrm{a}\end{array}$ & $\begin{array}{l}100.5 \pm 19.8 \mathrm{a} \\
51.1 \pm 8.7 \mathrm{~b} \\
71.7 \pm 11.6 \mathrm{~b}\end{array}$ & $\begin{array}{c}104.3 \pm 26.6 \mathrm{a} \\
47.4 \pm 9.2 \mathrm{~b} \\
91.1 \pm 21.1 \mathrm{ab}\end{array}$ & $86.9 \pm 28.3 \mathrm{a}$ & $\begin{array}{l}F=4.53 ; P=0.001 ; \text { d.f. }=3,72 \\
F=65.12 ; P=0.001 ; \text { d.f. }=2,72 \\
F=3.17 ; P=0.04 ; \text { d.f. }=2,72\end{array}$ \\
\hline $\begin{array}{l}\text { (e) Experiment } \\
\text { Nozzle } \\
\text { Region } \\
\text { Surfactant }\end{array}$ & $\begin{array}{l}- \\
123.8 \pm 16.0 \mathrm{a} \\
8.6 \pm 0.7 \mathrm{~b}\end{array}$ & $\begin{array}{l}104.2 \pm 13.1 \mathrm{a} \\
112.3 \pm 15.9 \mathrm{ab} \\
145.4 \pm 132.0 \mathrm{a}\end{array}$ & $\begin{array}{r}83.9 \pm 10.9 \mathrm{~b} \\
95.1 \pm 14.5 \mathrm{~b} \\
145.9 \pm 6.9 \mathrm{a}\end{array}$ & $\begin{array}{c}118.8 \pm 13.6 \mathrm{a} \\
68.6 \pm 9.8 \mathrm{c}\end{array}$ & $\begin{array}{l}F=5.06 ; P=0.001 ; \text { d.f. }=2,108 \\
F=10.50 ; P=0.001 ; \text { d.f. }=3,108 \\
F=152.41 ; P=0.001 ; \text { d.f. }=2,108\end{array}$ \\
\hline $\begin{array}{l}\text { (f) Experiment } \\
\text { Nozzle } \\
\text { Region } \\
\text { Surfactant }\end{array}$ & $\begin{array}{l}- \\
130.5 \pm 16.3 \mathrm{a} \\
12.6 \pm 1.2 \mathrm{~b}\end{array}$ & $\begin{array}{l}129.6 \pm 17.3 \mathrm{ab} \\
141.3 \pm 20.7 \mathrm{a} \\
188.2 \pm 10.6 \mathrm{a}\end{array}$ & $\begin{array}{l}104.3 \pm 13.9 \mathrm{~b} \\
134.6 \pm 22.2 \mathrm{a} \\
165.8 \pm 16.6 \mathrm{a}\end{array}$ & $\begin{array}{r}132.7 \pm 16.6 \mathrm{a} \\
82.5 \pm 12.1 \mathrm{~b}\end{array}$ & $\begin{array}{l}F=2.81 ; P=0.06 ; \text { d.f. }=2,108 \\
F=6.26 ; P=0.001 ; \text { d.f. }=3,108 \\
F=105.9 ; P=0.001 ; \text { d.f. }=2,108\end{array}$ \\
\hline
\end{tabular}

-, Nozzle not evaluated.

*Means within a row followed by the same letters are not significantly different as indicated by ANOVA and Fisher's protected LSD $(P<0.05)$.

107.7 FSU/onion on Region 2. While observed differences in tracer recovery in Region 1, frequently the refuge for immature OT, were not statistically significant, more tracer tended to be recovered when applied in combination with Sylgard or Companion using the XR flat nozzles than when applied using either D4/DC25 or TJ60 8004 nozzles (Fig. 2a).

In experiment 2, the $\mathrm{D} 4 / \mathrm{DC} 25$ disc-core nozzle deposited significantly more tracer onto sprayed onions than any of the other nozzles tested (Table 2b). Significantly less tracer was recorded on onion leaves when Sylgard was applied. The highest amount of tracer was recorded in Region 1 $(65.5 \%)$, significantly more than Region $2(18.8 \%)$ or Region $3(15.7 \%)$. A significant interaction among nozzles, surfactants and regions was not observed $(F=0.79$; $P=0.66$; d.f. $=12,72)$. In Region 1 , when tracer + Companion was applied by either the XR8004 or TJ60 8004 nozzle, significantly less tracer was detected than on leaves sprayed with the XR8003 or D4/DC25 nozzles (Fig. 2b).

In experiment 3, the XR8004 flat fan nozzle deposited significantly more tracer onto sprayed onions than any of the other nozzles tested (Table 2c). Significantly more tracer was recorded on onion leaves when Sylgard was added to the spray mixture. The highest amount of tracer was recorded in Region 1. Further analysis revealed a significant interaction among nozzles and surfactants $(F=3.62 ; \quad P=0.00 ; \quad$ d.f. $=6,72)$. The XR8004 nozzle combined with Sylgard resulted in significantly more tracer (117.9 FSU) than any other combination. A comparison of spray deposition among nozzles in Region 1 revealed that although not statistically different, more tracer was deposited when tracer + Sylgard were applied using either XR8004 or D4/DC 25 nozzles (Fig. 2c). Conversely, significantly less tracer was detected in Region 1 when onions were sprayed with tracer+Companion by the XR8003, XR8004 or TJ60 8004 nozzles.

In experiment 4 , significantly more tracer was deposited onto onion leaves by XR8004, D4/DC25 and TJ60 8004 nozzles than the XR8003 nozzle (Table 2d). Significantly more tracer was recorded on leaves when Sylgard or no surfactant were added to the spray mixture. The highest amount of tracer was recorded on Region 1 of the onion leaves. A significant interaction existed among nozzles, surfactants and regions on this spray date $(F=9.11$; 

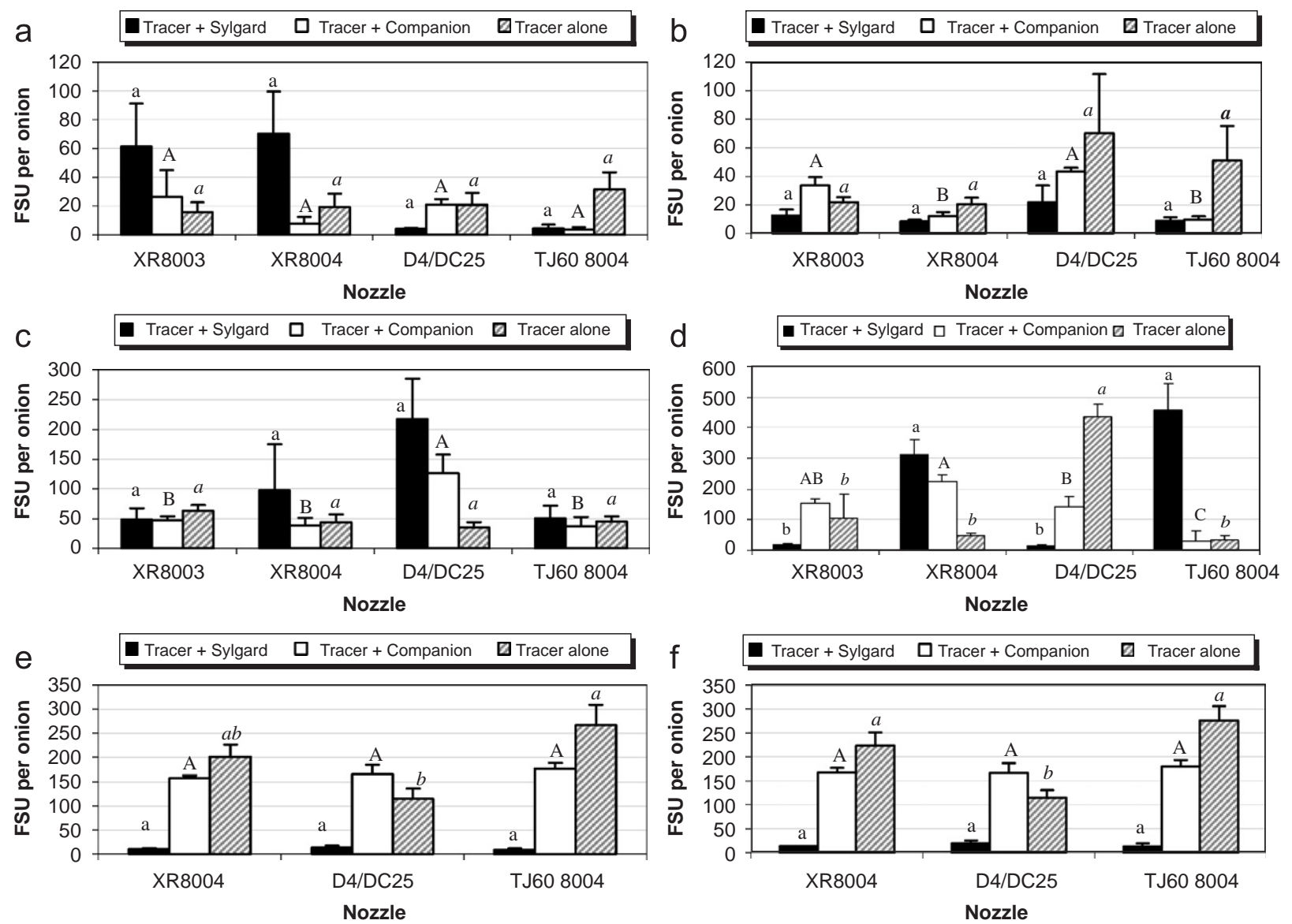

Fig. 2. Spray deposition, as measured by fluorescence units (FSU), of Tinopal CBS-X mixed with surfactants on Region 1 of onion leaves applied in $200 \mathrm{~L} / \mathrm{ha}(\mathrm{a}, \mathrm{b}, \mathrm{c})$ or $400 \mathrm{~L} / \mathrm{ha}(\mathrm{d}, \mathrm{e}, \mathrm{f})$ at $276 \mathrm{kPa}$ in a track sprayer. For each experiment, a comparison of each surfactant across nozzle type was determined by ANOVA and Fisher's protected LSD test; columns followed by the same letters (either capitalized or italicized) are not significantly different $(P<0.05)$.

$P=0.001 ;$ d.f. $=12,72)$. Two treatment combinations delivered significantly more tracer than all other combinations tested. The TJ60-8004 nozzle combined with Sylgard and the D4/DC25 nozzle with no surfactant delivered 456.9 and 436.4 FSU, respectively, to Region 1 . The next best treatment was the XR8004 nozzle combined with Sylgard (311.6 FSU) (Fig. 2d).

In experiments 5 and 6 , the carrier volume was increased from 200 to $400 \mathrm{~L} / \mathrm{ha}$. Regardless of experimental date, onion plants sprayed with Companion or no surfactant had significantly more tracer than onion plants sprayed with Sylgard and tracer mixture (Table 2e,f). In experiment 5 , onion plants sprayed with Sylgard retained $2.9 \%$ of the total tracer recorded, which was significantly less than plants sprayed with Companion $(48.5 \%)$ or no surfactant $(48.6 \%)$. In experiment 6 , onion plants sprayed with Sylgard retained only $3.4 \%$ of the total tracer recorded, significantly less than plants sprayed with Companion $(51.3 \%)$ or no surfactant $(45.2 \%)$.

In experiment 5 , more tracer was recorded in Region 1 than any other region while in experiment 6 , Regions 1-3 were not significantly different from each other. Further analysis revealed a significant interaction among nozzles, surfactants and regions in both experiments (experiment 5 : $F=3.97 ; P=0.00$; d.f. $=12,108$ ), (experiment $6: F=3.16$; $P=0.001 ;$ d.f. $=12,108)$. In experiment 5 , significantly more tracer was detected in the absence of either surfactant on onions sprayed with the TJ60 8004 (Region 1, 266.6 FSU), XR8004 (Region 2, 218.5 FSU) or D4/DC25 (Region 2, 211.2 FSU) nozzles. Comparison of tracer deposition among nozzles revealed more tracer was detected in Region 1 when applied by XR8004 or TJ60 8004 in the absence of surfactant (Fig. 2e).

In experiment 6 , significantly more tracer was detected in all three regions of onion plants sprayed with the XR8004 in the absence of surfactant (Region 1, 223.4 FSU; Region 2, 259.3 FSU; Region 3, 270 FSU) and TJ60 8004 nozzles in the absence of surfactant (Region 1, 275.9 FSU) or when combined with Companion (Region 2, 263.8 FSU; Region 3, 287 FSU). Significantly more tracer was also detected in Region 2 of onion plants sprayed with the D4/DC25 nozzle in the absence of surfactant (256.3 FSU) or when combined with Companion (239.5 FSU). Similar to the results observed in experiment 5 , significantly more tracer was detected in Region 1 when applied with XR8004 or TJ60 8004 in the absence of surfactant (Fig. 2f). 


\subsection{Field sprayer trial}

Due to the inconsistent and/or poor performance of Companion, especially when compared to treatments receiving no surfactant in the track sprayer trials, two different non-ionic surfactants, Agral 90 and LI700, were tested along with Sylgard in the field.

Significantly more tracer was detected on the inner leaves of onion plants sprayed with the XR8004 nozzle than on leaves sprayed with the D4/DC25 disc-core nozzle
$(F=32.77 ; P=0.001 ;$ d.f. $=1,77)($ Table 3$)$. In addition, a significant difference was observed among surfactants $(F=19.95 ; \quad P=0.001 ;$ d.f. $=3,77)$ and between carrier volumes $(F=5.83 ; P=0.01 ;$ d.f. $=1,77)$. A significant interaction between nozzles, surfactants and volumes was also observed $(F=3.28 ; P=0.02$; d.f. $=3,77)$. The best nozzle, surfactant, carrier volume combination was the XR8004 nozzle combined with Agral 90 at both 400 and $600 \mathrm{~L} / \mathrm{ha}$; which respectively covered $29 \%$ and $23 \%$ of treated inner leaves (Fig. 3a). The next best combination,

Table 3

Effectiveness of combination treatments of nozzles (1, TeeJet ${ }^{\circledR}$ XR8004; 2, TeeJet ${ }^{\circledR}$ D4/DC25 disc core), surfactants $\left(1\right.$, no surfactant; 2, Sylgard ${ }^{\circledR} 309 ; 3$, LI-700 ${ }^{\circledR} ; 4$, Agral $\left.{ }^{\circledR} 90\right)$ and carrier volumes $(1,400 \mathrm{~L} /$ ha; $2,600 \mathrm{~L} /$ ha $)$ for mean percent coverage of Tinopal CBS-X onto onion leaves, applied by a R\&D field plot sprayer

\begin{tabular}{|c|c|c|c|c|}
\hline \multirow[t]{2}{*}{ Parameter } & \multicolumn{4}{|c|}{ Mean $\%$ coverage \pm SEM } \\
\hline & 1 & 2 & 3 & 4 \\
\hline $\begin{array}{l}\text { Nozzle } \\
\text { Surfactant } \\
\text { Volume }\end{array}$ & $\begin{array}{r}14.2 \pm 1.7 \mathrm{a}^{*} \\
5.4 \pm 1.0 \mathrm{c} \\
7.7 \pm 1.4 \mathrm{~b}\end{array}$ & $\begin{array}{r}4.4 \pm 0.7 \mathrm{~b} \\
3.9 \pm 1.2 \mathrm{c} \\
10.9 \pm 1.5 \mathrm{a}\end{array}$ & $10.9 \pm 2.2 \mathrm{~b}$ & $17.1 \pm 2.4 \mathrm{a}$ \\
\hline \multirow[t]{9}{*}{ Nozzle $\times$ surfactant $\times$ volume } & Nozzle & Surfactant & Volume & Mean $\%$ coverage \\
\hline & $\begin{array}{l}1 \\
1\end{array}$ & $\begin{array}{l}1 \\
1\end{array}$ & $\begin{array}{l}1 \\
2\end{array}$ & $\begin{array}{l}7.3 \text { defgh }^{* *} \\
9.3 \text { def }\end{array}$ \\
\hline & $\begin{array}{l}1 \\
1\end{array}$ & $\begin{array}{l}2 \\
2\end{array}$ & $\begin{array}{l}1 \\
2\end{array}$ & $\begin{array}{l}1.9 \mathrm{fgh} \\
12.6 \mathrm{~cd}\end{array}$ \\
\hline & $\begin{array}{l}1 \\
1\end{array}$ & $\begin{array}{l}3 \\
3\end{array}$ & $\begin{array}{l}1 \\
2\end{array}$ & $\begin{array}{l}11.1 \mathrm{cde} \\
18.4 \mathrm{bc}\end{array}$ \\
\hline & $\begin{array}{l}1 \\
1\end{array}$ & $\begin{array}{l}4 \\
4\end{array}$ & $\begin{array}{l}1 \\
2\end{array}$ & $\begin{array}{l}29.8 \mathrm{a} \\
23.2 \mathrm{ab}\end{array}$ \\
\hline & $\begin{array}{l}2 \\
2\end{array}$ & $\begin{array}{l}1 \\
1\end{array}$ & $\begin{array}{l}1 \\
2\end{array}$ & $\begin{array}{l}0.5 \mathrm{~h} \\
4.2 \mathrm{efgh}\end{array}$ \\
\hline & $\begin{array}{l}2 \\
2\end{array}$ & $\begin{array}{l}2 \\
2\end{array}$ & $\begin{array}{l}1 \\
2\end{array}$ & $\begin{array}{l}0.1 \mathrm{~h} \\
0.9 \mathrm{gh}\end{array}$ \\
\hline & $\begin{array}{l}2 \\
2\end{array}$ & $\begin{array}{l}3 \\
3\end{array}$ & $\begin{array}{l}1 \\
2\end{array}$ & $\begin{array}{l}6.1 \text { defgh } \\
8.2 \text { defg }\end{array}$ \\
\hline & $\begin{array}{l}2 \\
2\end{array}$ & $\begin{array}{l}4 \\
4\end{array}$ & $\begin{array}{l}1 \\
2\end{array}$ & $\begin{array}{l}4.6 \text { efgh } \\
10.7 \mathrm{de}\end{array}$ \\
\hline
\end{tabular}

* Means within a row followed by the same letters are not significantly different as indicated by ANOVA and Fisher's protected LSD $(P<0.05)$.

${ }^{* *}$ Means within the column followed by the same letters are not significantly different as indicated by ANOVA and Fisher's protected LSD $(P<0.05)$.
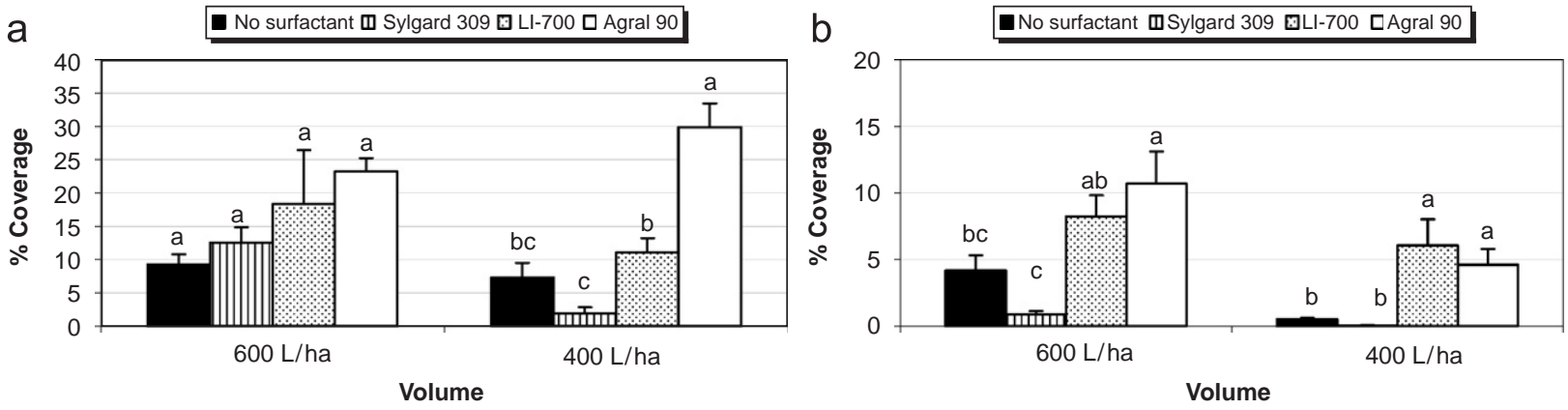

Fig. 3. Percent coverage of the tracer, Tinopal CBS-X, mixed with surfactants on onion leaves in two carrier volumes at $276 \mathrm{kPa}$ applied using an R\&D field plot sprayer. Within a carrier volume for a given nozzle, columns followed by the same letters are not significantly different $(P<0.05)$ as determined by ANOVA and Fisher's protected LSD. 
XR8004, LI-700 at $600 \mathrm{~L} /$ ha, delivered $18 \%$ coverage. For the D4/DC25 disc-core nozzle, more tracer was observed at both volumes when combined with either LI-700 or Agral 90 (Fig. 3b). However, the percent coverage of this nozzle was markedly less than that observed on onions sprayed with the XR8004 nozzle.

\section{Discussion}

Onion thrips are thigmotactic, preferring to congregate deep within the axils of the youngest onion leaves throughout the growing season. This behaviour offers protection from predators, from environmental stresses and possibly from control agents. A better understanding of the interactions of insecticide application and insect behaviour can benefit growers in their battle to control onion thrips. Improved delivery of insecticides into the leaf axils of onion plants will improve control of onion thrips and may reduce the overall number of pesticide applications required.

Track sprayer work demonstrated that on small onion plants (4-5-leaf stage), application of carrier mixed with Sylgard via either an XR8004 or D4/DC25 nozzle, delivered the most tracer into the lowest region of the inner leaves when applied in a carrier volume of $200 \mathrm{~L} / \mathrm{ha}$. When the carrier volume was doubled to $400 \mathrm{~L} /$ ha, less tracer was detected when mixed with Sylgard regardless of the nozzle tested. Sylgard is an organo-silicone surfactant. Studies have shown that non-ionic surfactants can lower the surface tension of a spray solution to $33-34 \mathrm{mN} / \mathrm{m}$; the addition of a silicone component can further lower the surface tension to $22 \mathrm{mN} / \mathrm{m}$ (Penner, 2000). However, this very characteristic may lead droplets to coalesce and subsequently run off the plant (Petroff, 2003). Therefore, it is possible that during the second track sprayer pass, required to deliver the higher volume, there was greater tendency for the tracer + Sylgard combination to run off treated onion plants. Based on these findings, growers may be able to increase effectiveness of foliar sprays for onion thrips control on young onion plants by adding Sylgard rather than increasing carrier volume. However, the lack of consistency among experiments $1-4$ is important to note. Based on these results, it is difficult to make any firm recommendations based on track sprayer results alone.

In Canada, eight non-ionic surfactants, falling into one of six different chemical composition categories, are registered for agricultural uses. In the track sprayer trials, two types of non-ionic surfactants were studied, an octylphenoxy-polyethoxy-9-ethanol (Companion) and a silicone polyether (Sylgard). Following the poor results following the application of Companion, the authors decided to evaluate non-ionic surfactants from two different chemical composition categories, Agral 90 (nonylphenoxy polyethoxyethanol) and LI700 (phosphatidycholine, methlacetic acid, alky polyoxyethylene ether) in addition to Sylgard in the field.
Although the track sprayer data demonstrated that application of Sylgard at a higher carrier volume did not increase coverage, higher carrier volumes were evaluated under field conditions for two reasons. Firstly, field experiments were performed on large, older plants with greater leaf surface area, thereby requiring more water for coverage. Secondly, in Ontario, a general recommendation in the war against onion thrips is to increase carrier volumes. Therefore, it was important to test different surfactants at higher water rates under field conditions.

In the field sprayer trial, mature onion plants (eight-leaf stage) sprayed with tracer+Agral 90 via the XR8004 nozzle displayed the best coverage of the inner leaves at both carrier volumes tested. In fact, less tracer was detected on the inner leaves of plants sprayed with any tracer + surfactant combination using the D4/DC25 nozzle. Observed differences between the two nozzle types may be due to the droplet size or volume mean diameter (VMD). At $276 \mathrm{kPa}$, the XR8004 flat fan nozzle delivers droplets with a VMD of approximately $330 \mu \mathrm{m}$ (Anonymous, 1993). Published data report that the D4/DC25 disc-core nozzle delivers droplets with VMD of 320 and 275 at 167 and $333 \mathrm{kPa}$, respectively (Anonymous, 1967). Based on the pressure used in these experiments $(276 \mathrm{kPa})$, the VMD of droplets delivered with a D4/DC25 nozzle would have been smaller than those delivered by XR8004. In the track sprayer trial, the younger, smaller onions were a difficult target to wet, and the D4/DC25 disc-core nozzle may have more successfully delivered spray droplets into the leaf axils because there were fewer leaves and more leaf surface was contacted by the smaller droplets. As well, drops produced by this nozzle type may have provided greater overall coverage and been more mobile on younger, waxier leaves. In the field trial, mature onion plants (8-9-leaf stage) had taller, wider individual leaves and the inner leaves were less appressed compared to young plants used in track sprayer trials. Therefore, movement of the smaller droplets produced by the D4/DC25 nozzle may have been slowed by environmentally abraded older leaves or the droplets may have dried on contact rather than running down the insides of the inner leaves. In addition, plants in the field trial may have dried more quickly than onion plants sprayed in track sprayer trials. Weather records taken at time of spray application indicated that the air temperature and relative humidity were $29^{\circ} \mathrm{C}$ and $56 \%$, respectively. By the time the plants were harvested, the temperature had risen to $33{ }^{\circ} \mathrm{C}$ and the relative humidity had fallen to approximately $50 \%$. Temperature and relative humidity may also help to explain why the addition of Sylgard, under field conditions, did not increase percent coverage in the inner leaves, as observed in track sprayer trials. Following application in the field, plants sprayed with Sylgard appeared 'wetter' than plants sprayed with other treatment combinations. In general, organosilicone adjuvants (e.g. Sylgard), are noted for their superior spreading abilities and extremely low surface tensions (Sun, 1996). Murphy et al. (1991) showed that solutions containing 
organosilicones dramatically increased the relative spread area compared to conventional adjuvants by reducing the contact angle between droplets and the intended surface. If the contact angle is reduced too much, the spray droplet may either have a tendency to dry more quickly on contact or, in higher water volumes, run off the contacted surface. Considering the ambient air temperatures and low relative humidity at the time of application and harvest, it is possible that droplets dried quickly on contact and did not run into the leaf axil. It is also possible that with the increased carrier volumes there was more run off and thus less tracer deposited on the onion leaves. In the track sprayer trials, less tracer + Sylgard was detected in Region 1, regardless of nozzle, when the carrier volume was increased. Application of a lower volume of carrier (e.g. $200 \mathrm{~L} /$ ha) may have resulted in retention of more tracer on the leaf surface.

The addition of surfactants should help to lower the surface tension allowing droplets to hit and run, regardless of nozzle type. This was observed when onion plants were sprayed using the D4/DC25 nozzle. The addition of either LI-700 or Agral 90 increased the overall coverage of onion leaves sprayed from $2 \%$ to $3 \%$ at $400 \mathrm{~L} /$ ha and $9 \%$ to $12 \%$ at $600 \mathrm{~L} / \mathrm{ha}$.

In the absence of any surfactant, plants sprayed with the XR8004 flat fan had $14 \times$ greater coverage of the inner leaves than plants sprayed with D4/DC25 hollow cone at $400 \mathrm{~L} /$ ha and $2 \times$ greater coverage when applied at $600 \mathrm{~L} / \mathrm{ha}$. With the addition of Agral 90, application using the XR8004 nozzle resulted in $30 \%$ coverage at $400 \mathrm{~L} /$ ha and $23 \%$ coverage at $600 \mathrm{~L} /$ ha.

The goal of this work was to observe spray coverage patterns of different nozzles, surfactants and carrier volumes on onion plants in the hope of identifying a combination that best delivered spray solution into the leaf axils of onion plants to better target onion thrips populations. Based on the results of this work, choosing the right nozzle, surfactant and carrier volume is critical. The wrong combination of nozzle, surfactant and insecticide will cost the grower time and money. When the insecticide is not delivered to the onion leaf axils, onion thrips numbers will not be reduced, populations will continue to increase and the grower will be forced to make more spray applications in an attempt to control the pest. With only two classes of insecticides registered for control of onion thrips in Ontario, when more sprays are needed, the development of insecticide resistance becomes a valid concern. Therefore, identifying the best combination of nozzle, surfactant and carrier volume is important for both economic and environmental reasons.

As mentioned earlier, this work demonstrated that extrapolations regarding spray application from the laboratory to the field are not always valid. These laboratory and field trials did, however, emphasize the need for further research into various mechanical parameters associated with insecticide application for management of a cryptic pest such as onion thrips.

\section{Conclusions}

Efficacious delivery of a pest control agent to the location of the pest organism is perhaps the weakest link in the chain of events leading from identification of the pest and selection of the control agent to satisfactory control of that pest. This work demonstrated great variation in the amount of tracer detected in the target treatment area depending on the nozzle, the presence and type of surfactant and the carrier volume. Under field conditions, Agral 90 delivered the best coverage regardless of carrier volume or nozzle type. With that said, it is important that growers exercise care when choosing a suitable surfactant and carrier volume for onion thrips control as certain surfactant/carrier volume combinations did not adequately deliver materials to the target site.

It is thus advisable to further investigate various parameters associated with insecticide application under field conditions to maximize control while minimizing the number of insecticide applications. Based on this preliminary research, we recommend that onion growers add a suitable surfactant to registered insecticides and apply using TeeJet ${ }^{\circledR}$ XR8004 flat fan spray nozzles.

\section{Acknowledgements}

The authors would like to thank Alex Molnar of Agriculture and Agri-Food Canada for creating the onion plant illustration. We gratefully acknowledge financial support from Food Systems 2002 OMAFRA, Ontario Fruit and Vegetable Growers' Association, ThedfordGrand Bend Vegetable Association and Agriculture and Agri-Food Canada.

\section{References}

Anonymous, 1967. XR TeeJet extended range flat spray tips volume median diameter versus pressure curves. Data Sheet No. 11825-43. Spraying Systems Co.

Anonymous, 1975. Cereal evaluation. In: CIBA-GEIGY Field Trial Manual. ciba-GEIGY, Basle, Switzerland.

Anonymous, 1993. Spray particle size versus orifice disc no. with various core sizes bases on spraying water at $70^{\circ} \mathrm{F}$. Data Sheet No. 11825-10. Spraying Systems Co.

Barber, J.A.S., Parkin, C.S., 2003. Fluorescent tracer techniques for measuring the quantity of pesticide deposited to soil following soil application. Crop Prot. 22, 14-21.

Barber, J.A.S., Parkin, C.S., Chowdhury, A.B.M.N.U., 2003. Effect of application method on control of powdery mildew (Blumeria graminis) on spring barley. Crop Prot. 22, 949-957.

Boyce, K.E., Miller, L.A., 1954. Overwintering habitats of the onion thrips, Thrips tabaci Lind. (Thysanoptera: Thripidae) in southwestern Ontario. Rep. Entomol. Soc. Ont. 84, 82-86.

Brewster, J.L., 1994. Onions and Other Vegetable Alliums. CAB International, Oxon, UK, 236pp.

Crosby, D.G., 1973. The fate of pesticides in the environment. Annu. Rev. Plant Physiol. 24, 467-492.

Downer, R.A., Kirchner, L.M., Hall, F.R., Bishop, B.L., 1997. Comparison of droplet spectra of fluorescent tracers commonly used to measure pesticide deposition and drift. In: Goss, G.R., Hopkinson, 
M.J., Collin, H.M. (Eds.), Pesticide Formulation and Application Systems, pp. 115-128.

Dynex, 1999. Dynex Technologies Software. Virginia, USA.

Hall, F.R., Adams, A.J., 1990. Microdroplet application for determination of comparative topical and residual efficacy of formulated permethrin to two populations of diamondback moth (Plutella xylostella L.). Pest Sci. 28, 337-343.

Harris, C.R., Svec, H.J., Sans, W.W., 1971. Toxicological studies on cutworms. VII Micro-plot field experiments on the effectiveness of four experimental insecticides applied as rye cover crop and soil treatments for control of the dark-sided cutworm. J. Econ. Entomol. 64, 493-496.

Horsfall, J.L., Fenton, F.A., 1922. Onion thrips in Iowa. Bull.Iowa Exp. Station 205, 54-68.

Howard, R.J., Garland, J.A., Seaman, W.L., 1994. Onion, garlic, leek, shallot, chives. In: Diseases and Pests of Vegetable Crops in Canada, pp. 178-197.

Lewis, T., 1997. Thrips as Crop Pests. CAB International, New York, 740pp.

MacIntyre-Allen, J.K., 2004. Population dynamics, insecticide resistance and management of onion thrips, Thrips tabaci Lindeman, in southwestern Ontario. Ph.D. Thesis. University of Guelph, 239pp.

McKenzie, C.L., Cartwright, B., Miller, M.E., Edelson, J.V., 1993. Injury to onions by Thrips tabaci (Thysanoptera: Thripidae) and its role in the development of purple blotch. Environ. Entomol. 22, 1266-1277.

Molenaar, N.D., 1984. Genetics, Thrips (Thrips tabaci L.), resistance and epicuticular wax characteristics of nonglossy and glossy onions (Allium cepa L.) Ph.D. Thesis, University of Wisconsin-Madison.
Murai, T., 2000. Effect of temperature on development and reproduction of the onion thrips, Thrips tabaci Lindeman (Thysanoptera: Thripidae), on pollen and honey solution. Appl. Entomol. Zool. 35, 499-504.

Murphy, G.J., Policello, G.A., Ruckle, R.E., 1991. Formulation consideration for trisiloxane based organosilicone adjuvants. In: Proceedings of Brighton Crop Protection Conference, Weeds, pp. 355-362.

OMAFRA, 2006. Vegetable Production Recommendations 2006-2007. Publication 363. Queen's Printer for Ontario, 210pp.

Penner, D., 2000. Activator adjuvants. Weed Tech. 14, 785-791.

Petroff, R., 2003. Pesticide adjuvants and surfactants. Montana State University, 〈http://scarab.msu.montana.edu/extension/agadj003.htm $\rangle$.

Sites, R.W., Chambers, W.S., Nichols, B.J., 1992. Diel periodicity of thrips (Thysanoptera: Thripidae) dispersion and the occurrence of Frankliniella williamsi on onions. J. Econ. Entomol. 85, 100-105.

Staniland, L.N., 1958. Fluorescent tracer techniques for the study of spray and dust deposits. J. Agric. Eng. Res. 3, 110-125.

Sun, J., 1996. Characterization of organosilicone surfactants and their effects on sulfonylurea herbicide activity. Ph.D. Thesis, Virginia Polytechnic Institute and State University, 133pp.

Theunissen, J., Legutowska, H., 1991. Thrips tabaci Lindeman (Thysanoptera: Thripidae) in leek: within plant distribution. J. Appl. Entomol. 112, 309-316. 